\title{
Human rights - the tension and conflict between \\ church and state in Malawi: 2004-2012
}

NGTT DEEL 55, NO 1, 2014

\section{Mbaya, Henry}

Stellenbosch University

\begin{abstract}
In this paper, I show the critical role played by the Protestant and the Roman Catholic Churches with regard to the government's abuse of human rights in Malawi in the years 2004 to 2012. I argue that the Protestant and Catholic leaders' response to Bingu wa Mutharika's government's violation of human rights was influenced by a number of factors: first, the Church leaders' perceptions of Wa Mutharika's uneasiness about their critical voice. Second were the Church leaders' perceptions of the weak position of the government. Finally, I argue that though not always uniform or consistent, the churches prophetic voice was occasionally undermined by their partisan interests, which sometimes were exploited by the government.
\end{abstract}




\section{INTRODUCTION}

This article will highlight the prophetic witness of the Protestant and the Roman Catholic Churches in Malawi in response to the issues of human rights and governance during the era of the government of President Bingu wa Mutharika in the years 2004-2012. The study will illustrate that in spite of its critical voice against human rights abuse and issues of governance, the Churches' social witness was also undermined by its own weakness of divisions and inability to observe human rights within its own ranks. The study will show that though the Churches did not always speak with one voice, nevertheless their sustained witness tried to highlight the socio-economic and political issues that the country faced during the presidency of wa Mutharika. Wa Mutharika was the third State President of the Republic of Malawi after Bakili Muluzi (1994-2004), the latter succeeded Hastings Kamuzu Banda, the first democratically elected President at Malawi's independence in 1964. President Mutharika died in office in 2012, when President Joyce Banda succeeded him.

\section{1 "Church power" as a factor in wa Mutharika's presidency: 2004}

If Rene Dumont's thesis that Africa had 'a false start' at independence following African dictators' perpetuation of colonial monopoly of power with its excesses (Fortman 2004: 3) is correct, perhaps to a degree it can also be said that in 2004 Malawi had a 'false start'. Constitutionally barred to run for a third term, and marginalising his 'obvious successor', Vice President Justin Malewezi (Gama 2010: 161), the former State President, Bakili Muluzi, 'anointed' Bingu wa Mutharika, hitherto unknown in the party, to succeed him in 2004.

Previously not a Catholic, in 2003, a year before he came to power, wa Mutharika embraced Roman Catholicism (The Maravi Post, 22/5/11). ${ }^{1}$ As The Maravi Post put it, he 'joined the Church in 2003 in order to gain the support from the huge Catholic community (The Maravi Post, 22/5/11).' When he became president in 2004 wa Mutharika knew well that since the 1992 epoch-making Catholic bishops' Pastoral Letter, it was the Roman Catholic and to some extent the Presbyterian Churches which wielded tremendous 'political' influence on the Malawian society.

A narrow margin win at the polls appears to have placed wa Mutharika's government in a much weaker position in relation to the powerful opposition parties, Malawi

1 http://www.maravipost.com/Malawi-scope/op-ed225-2011-ayear-of-missed-opportunities, accessed June 25, 2012.

2 http://www.maravipost.com/Malawi-scope/op-ed225-2011-ayear-of-missed-opportunities, accessed June 25, 2012. 
Congress Party and United Democratic Party in parliament from 2004 to 2009. Hence this paper will seek to address the issue of the response of the Protestant and Roman Catholic Church leaders in Malawi to the government's abuse of human rights in the years 2004-2012. It will seek to illustrate that amongst other factors, the apparent initial weak position of the wa Mutharika's government, President Bingu wa Mutharika's attitude towards the Churches' critical voice and of the opposition parties and the NGOs, influenced the Churches' response to the government's abuse of human rights.

\section{THE RISE OF DICTATORIAL TENDENCIES}

\subsection{Mounting church-state confrontation - widening divisions in the churches: 2008-2010}

The year 2010 was critical for Malawi for the following developments: a 'gay couple' was arrested and sentenced, the new national flag was launched amidst controversy - in a ceremony where all the Church leaders were not involved except for the Anglican Bishop of Upper Shire Diocese, economic woes continued; then the President called upon the members of his Democratic Progressive Party to beat up those who insulted him. ${ }^{3}$ In response to these developments, according to Reverend Macdonald Kadawati, then Chairman of the Public Affairs Committee Public Affairs Committee General Secretary of Blantyre Synod, the Public Affairs Committee issued a general communiqué at Lilongwe Hotel on 13 August 2012 and in The Nation of 12 March 2011 in which they condemned the laws (Questionnaire, Telephone interviews, 15/05/12; 21/05/12).

\subsubsection{Catholic Bishops' pastoral letter - "The signs of the times"}

It is in this context that on 31 October 2010 the Catholic Bishops issued a Pastoral Letter entitled, 'The Signs of the Times' (The Nation, 2/11/10). ${ }^{4}$ Unlike the landmark Pastoral Letter of 1992, the language of this letter was mild. Reflective in tone, the bishops took as their point of departure the Scriptural texts Ezekiel 33:7 and Luke 12:54-56 and Church tradition Gaudium et Spes, paragraph 1. Commending government's efforts towards food security, the bishops then went out to condemn a wide range of issues, notably the lack of proper consultations on national issues, the lack of respect for the office of the Vice President, the use of public media to

3 http://bbc.co.uk/news/world-africa-13881367, accessed June 20, 2012.

4 http://www.trademarksa.org/news/malawi-full-pastoral-letter-catholic-bishops, accessed June $20,2012$. 
muzzle dissent, corruption, the dislocation of people to give way for government development projects without making proper provisions for them. ${ }^{5}$ It is strange that the bishops made no reference to the issue of homosexuality during the time when there were not only national but also international ramifications following the arrest of Mr Chimbalanga and Mr Mongeza allegedly for their homosexual acts. The fact that it was not mentioned would seem to suggest that the Church was not yet ready to make a pronouncement on an issue that was very sensitive. However, this was to change only in 2013.

More significantly, the Bishops condemned what they called 'the big-man syndrome' when young new blood is not allowed to enter into political leadership. ${ }^{6}$ In other words, according to the Bishops, Mutharika's political style of leadership brooked no opposition, it was a kind of leadership that could be illustrated in the Malawian language proverb: 'Two cocks cannot crow in the same kraal', Atambala awiri salilira mkhola limodzi. The expulsion of the Vice President tended to demonstrate that 'competitive leadership' is not tolerated in Malawi culture.

The Bishops' statement also created divisions within the Churches; this was witnessed more particularly in the Presbyterian Blantyre Synod. At a press conference, Reverend Mmangisa, the Moderator of Blantyre Synod, attacked the bishops. In response, his colleague, Reverend Kadawati, the General Secretary, endorsed the Bishops' statement (Reverend Macdonald Kadawati, Questionnaire/Telephone Interviews, 15/05/12; 21/05/12). Thus Reverend Kadawati aligned the Synod with the position of the Catholic Church. Others construed the Moderator's attack on the bishops as a sign of his open support for the wa Mutharika government (Interview, Willie Zeze, Stellenbosch, 05/03/12).

According to the Church leaders, the socio-economic and political situation created a sense of national urgency to the extent that they resolved to see the President. It is said that a date originally set as 1 December 2010 for an appointment with the President was postponed indefinitely as the officials made every effort to obstruct the meeting from taking place (Interview, Reverends Davidson Chifungo and Bosman Chitheka, Stellenbosch, 25/03/12). It would seem the lack of the opportunity to see the President privately impelled some Church leaders to resort to communicating to the President on public forums. For instance, at the National Day of Prayer organised by the Episcopal Conference of Malawi (Catholic Bishops) and the Malawi Council

5 http://www.trademarksa.org/news/malawi-full-pastoral-letter-catholic-bishops, accessed June 20, 2012.

6 http://www.trademarksa.org/news/malawi-full-pastoral-letter-catholic-bishops, accessed June 20, 2012. 
of Churches (Protestant Church leaders) which the President attended in June 2011 at COMESA hall, in his sermon, the Roman Catholic Bishop of Mzuzu diocese, Joseph Mukasa Zuza, referred to 'those who have more authority' to threaten civil society, the faith community and the media in the face of the deteriorating social, economic, governance and political situation in Malawi (Nyasa Times, 25/08/11). ${ }^{7}$

At the International Trade Fair President wa Mutharika is reported to have responded saying that, 'A couple of days ago I was in that building (COMESA hall) over there. Somebody there, complete with a clerical collar on his shirtfront, was saying Bingu you are the most stupid person ndine chindere ndiwenso chitsiru. I want you to realise that I tolerate a lot; but some are mistaking this tolerance for stupidity. Please, that is wrong. When I stand up to fight back, you will see.' And then he went on to say, 'I can ... let this country go on fire if you want to...I want to tell you enough is enough! I can't stomach this insolence anymore (Malawi News, 25/08/11).' It is clear that President wa Mutharika had come to regard the Churches and the civil rights groups as his rivals. These seemed to stage themselves like the opposition parties, which were at this stage politically weak.

On several occasions the government tried to silence its critics by intimidating or harassing them and in some cases perpetrating violence against them. For instance, on 20 August 2010, following his preaching against wa Mutharika's style of leadership relating to the reshuffle of the cabinet ministers at a funeral, and the passing of unpopular bills, Reverend Levi Nyondo, the General Secretary of the Presbyterian Synod of Livingstonia Synod, was arrested (Malawi Today 20/08/10). ${ }^{8}$ Yet according to Reverend Mezuwa Banda, Educational Secretary of the Livingstonia Synod, not only did the church leaders keep silent over the arrest, worse still the Nkhoma Synod in Lilongwe condemned the Livingstonia Synod itself as deserving the treatment [and] that the Government was justified in taking the action (Questionnaire, 06/05/12). On the other hand, Reverend Fathers Macdonald Sembereka and Michael Mtambo, both Anglican priests highly critical of the government's abuse of human rights, had their houses petrol bombed allegedly by the government agents, as were the Roman Catholic Church's Secretariat offices in Lilongwe (Questionnaire/Telephone interview, 08/06/12).

7 http://www.nyasatimes.com2011/08/25/Mutharika-attacks-bishop-zuza, accessed May 10, 2012.

8 http://www.malawitoday.com/news/123279, accessed June 18, 2012. 


\section{THE ROLE OF THE PRESIDENTIAL RELIGIOUS ADVISER}

Divisions in the ranks of the clergy and the Churches have largely been attributed to the role of the Presidential Religious Advisor. Several respondents strongly claimed that the office of the Presidential Religious Advisor compromised the Churches' prophetic witness. For instance, Reverend Father Macdonald Sembereka claimed that he himself had been approached by the Religious Advisor who tried to 'buy him out of civil society' (Questionnaire/Telephone interview, 08/06/12). On the other hand, Reverend Mezuwa Banda noted that 'because of the perks that go with the office 'the holders of the office have put pressure [on] Churches to toe government's line'. He concluded saying that, 'they must be squarely blamed for the abuses' (Questionnaire, 06/05/12). Similarly, Reverend Macdonald Kadawati noted that 'the position became a political one as the advisor was used by the government/political masters to go out to distribute money with the aim of buying [government's] critics...'(Questionnaire/ Telephone Interviews, 15/05/12; 21/05/12). These assertions highlight the weakness usually associated with money and power, issues that tended to be divisive.

\section{THE ROLE OF THE CHURCH NGOS}

If the government used money to undermine the unity of the Churches, the international community sponsorship of human rights projects in the Churches became the front to criticise the government's human rights record.

Established on November 25, 1993, Blantyre Synod's Church and Society project concentrates on civic education, reporting and monitoring. It has designed a course to educate voters on their rights, which covers the theology of human rights, a course on democratic principles that covers the implications of voting, and basic human rights as contained in the international human rights conventions and other relevant instruments. The seminars are designed to train trainers, who will then proceed to the field and train others so as to facilitate the development of a communitybased scheme. The project also works closely with the other human rights groups. In an attempt to make Western notions of justice meaningful to the rural people in Malawi, to their credit, the officials of the project have adapted Western concepts and structures relating to justice to traditional Malawian equivalents, hence court 1 is bwalo 1 and court 2 is bwalo 2 (court 2).

The Presbyterian Synod of Livingstonia runs the largest local NGO in the Northern Region of Malawi and has co-operated with DanChurchAid since 2002. Human rights have become an important aspect of its work. Unlike the other human rights projects in the Presbyterian Church's Blantyre and Nkhoma Synods, in the Livingstonia Synod, the Church and Society project under the leadership of Moses 
Mkandawire has been more militant. It organised the national protest in Northern Malawi on 20 July 2010.

Nkhoma Synod in Central Malawi runs a Church and Society desk that was established in 2003 which covers 117 congregations. The Synod encourages its members to engage in the social and political affairs of the nation with the aim of promoting unity and peace in the country in safeguarding the rule of law and human rights.

To a degree the power behind the Roman Catholic Bishops' strong voice against human rights abuse is the Catholic Commission for Justice and Peace (CCJP). The CCJP was established in 1996, four years after the landmark Bishops' Pastoral Letter. It has translated the Malawi constitution in two languages that it distributes to villagers and educates them on human rights. It also works in partnership with government agencies and others to improve justice, democracy and governance.

Together with the NGOs, the Church projects on human rights receive funding for their programmes from overseas donors to whom they therefore are accountable. These include the Danish Fund for International Development, the Americansponsored TEAR Fund, the Danish International Development Aid (DaniDA), Danish Fund for Development and Norwegian Church Aid. Some of the directors of the NGOs having started as crusaders of human rights ended up being given posts in the wa Mutharika's government - consequently creating a perception that they sympathised with the government. For instance, Reverend Father Boniface Tamani of the Roman Catholic Church, who served as Public Affairs Committee Chairman (Public Affairs Committee) since 2001, was appointed to a committee of the Technical Advisor of the Malawi Bureau of Standards to the President, responsible for advising the President. These Overseas-funded organisations have raised an elitist group, graduates living in cities, whose socio-economic life starkly contrasts with that of the rural-based masses in the villages (Englund 2000: 5). ${ }^{9}$

That the President regarded the Churches and the NGOs as its enemies may be ascertained from his speech that he delivered during the graduation ceremony at Mzuzu University on 16 December 2010. He is quoted to have said, 'It was Jesus, the son of God who said turn the other cheek. Do you want me to be Jesus? That was Jesus, the son of God, I am Bingu, You slap me here, and I will hit you. That is the way life is. ${ }^{10}$ Yet President wa Mutharika was also very much aware of the role of the donor money in influencing the activities of the NGOs in criticising human rights

9 http://journals.cambridge.org/abstract S0022278X00003487, accessed April 2, 2013.

10 http://www.africaglobalvillage.com/pt/southern-Africa/ Malawi/471, accessed May 18, 2012. 
and governance issues. In his speech at the DPP rally in February 2011, President wa Mutharika accused donors of breaching the Venice Convention by supporting NGOs. ${ }^{11}$

As the Public Affairs Committee regularly and fiercely criticised the government's handling of human rights, the government viewed it as its adversary (Reverend Kadawati, Questionnaire/Telephone Interviews, 15/05/12; 21/05/12). As some Public Affairs Committee members witnessed violence perpetrated against some of the government's critics and experienced personal threats, they feared for their lives (Reverend Kadawati, Questionnaire/Telephone Interviews, 15/05/12; 21/05/12). Bishop James Tengatenga, Anglican bishop of Southern Malawi, asserted that fear of violence from the government security agents deterred some Church leaders outside the ranks of the Public Affairs Committee from involving themselves in its activities. He put it as follows, 'There were more serious issues involved. It was too dangerous - engagement is actually dangerous, real risk of bodily harm and other threats' (Questionnaire, 07/06/12).

As the leadership of the Public Affairs Committee found it increasingly difficult to raise their concerns with government officials including the President, it resorted to addressing the nation through the press. The Nation regularly published statements, which were critical of the government's handling of human rights and governance issues (Questionnaire/Telephone Interviews, Reverend Kadawati 15/05/12; 21/05/12). This angered the government to the extent that in March 2012, Mr Frank Mwenefumbo, National Youth Director of the ruling party DPP during the rally in Zomba, warned all civil servants to stop buying and reading the paper. ${ }^{12}$ Irritated by the activities of the human rights 'activist' clergy, government officials, notably, Mr Simoni Vuwa Kaunda, the Minister of Information and Government Spokesperson, and Dr. Hetherwick Ntaba, the Presidential Spokesperson, would at Press Conferences challenge them to join politics rather than 'hide under the cloak of religion' (Reverend Father Sembereka, Questionnaire/Telephone interview, 08/06/12). This would suggest that the government was more uncomfortable with the 'political' activities of the Church leaders than the opposition parties.

Nonetheless while the Church leaders have been fairly quick to respond to the violation of group human rights, they have tended to be slow or not strong enough when it came to individual rights. In 2011 human rights activists, Messrs John Kapito, Billy Mayaya, Brian Nyasulu, Habiba Osman, Ben Chiza Mkandawire and

11 http://www.institutions-africa.org/filestream/20111110, accessed 5 May 2012.

12 http://www.maravipost.com/Malawi-nation-news/Malawi-political-views/614, accessed June 2, 2012. 
Comfort Chiseko as well as Presidential candidate Atupele Muluzi were arrested and detained. Several respondents noted that 'the Churches were silent on this issue' (Bishop Tengatenga, Questionnaire, 07/06/12; Reverend Kadawati, Questionnaire/ Telephone Interviews, 15/05/12; 21/05/12). However, it was the Church leaders' organised national protest that was to shake the government.

\section{JULY 2011 NATIONAL PROTEST}

The Church leaders' failure to see the President to address the deteriorating economic crisis, worsening diplomatic relations with the neighbouring states and in particular the British government, governance issues, created a sense of national emergency. It was in view of this that the Catholic Bishops, leaders of the Public Affairs Committee (consisting largely of Protestant Churches), among others led by Bishop James Tengatenga, the Anglican Bishop of Southern Malawi, the civil society and others organised a national protest on 20 July 2011 with a view to putting pressure on the government to 'resign' or reform. During the course of the protest, acting under the provisions of the Police Bill Act of 2010, the police shot and killed 18 and arrested 2275 people. $^{13}$

In the aftermath of the police killing of four people in Kafukule, Mzimba district in Northern Malawi, Moses Mkandawire, the Director of Church and Society Programme of the Livingstonia Synod 'called for the establishment of the Police Complaints Commission as a means to end Malawi Police Services impunity. He went further to assert that, 'There is nobody to monitor their conduct which seems to be devoid of human rights. ${ }^{14}$ In the meantime, the Public Affairs Committee condemned the violence and the killings. Commenting on its activities, President Bakili Muluzi noted that at 'a critical time the Public Affairs Committee was a voice of the voiceless' in Malawi (Interview, former State President of Malawi, Bakili Muluzi, Stellenbosch, 17/06/12).

\section{NKHOMA SYNOD PASTORAL LETTER 2012}

In the meantime on 2 April 2012, Nkhoma Synod issued a Pastoral Letter entitled, 'Exercising Our Faith through Prayer, In Our Time, In Our nation'15 which

13 http://en.wikipedia.org/wiki/2011 Malawian_Protests, accessed June 12, 2012.

14 http://www.nyasatimes.com/Malawi/2012/02/02/church-calls-for-end-polcies-impunity, accessed May 18, 2012.

15 See http://munthalikondwani.blogspot.com/2012/04/full-ccap-nkhoma-synod-pastoral-letter. $\underline{\mathrm{html}}$, accessed 5/3/12. 
was critical of governance and human rights issues in society (Interview with Reverends Davidson Chifungo and Bosman Chitheka, Stellenbosch, 25/03/12). Their action surprised other Churches since for a long time the Synod had never publicly commented on governance and human rights issues. Unlike the Catholic Bishops' Pastoral Letter of 2010 which is theologically integrated, solidly backed by Scriptural references and tradition and was fairly direct in its thrust, this letter sounded like a litany of prayers, exhortations to the government, lacking sting. It exalted the faithful to pray for the alleviation of social ills in society, complained about unfulfilled promises of money and development projects from the President in Central Malawi, and gave advice to the President on justice issues. The Letter has three Scriptural references. It referred to their members 'as the light and salt of the world' (Matt. 5:13-16) and urged their members to pray for the nation because as the leadership stated 'whatever happens to our country politically, socially and economically will affect us too' (Jer. 29:7).

On the controversial issue of homosexuality, however, with no reference to Scriptural texts, the Pastoral Letter merely condemned the practice on the premise that it '[was] biblically and culturally an evil that dehumanises people and provokes God's wrath. ${ }^{16}$ No theological reflection was offered as to why they deemed homosexual as evil or why it was incompatible with 'Malawian culture.' That the Church leadership dismissed homosexuality merely on the basis that it was 'unbiblical' and 'incompatible' with Malawian culture would suggest that they had not yet worked out a theological stance to respond to a critical issue and consequently was not yet ready to engage seriously with the highly controversial issue that affected some Malawians.

The core of their criticism lay in the assertion,

We have to pray for our lawmakers to avoid being influenced by their political party biases when passing laws in parliament. Laws such as the Civil Procedures (Suits by or Against Government or Public Officers) including Injunctions, Section 46 of the Penal Code Amendment Act (discretionary control over the media)... only serve the interests of a few. ${ }^{17}$

The Letter concluded by citing John 8:12 asserting that 'Jesus is the Light to the world so are we. That Section 46 of the Penal Code caused a lot of pain and suffering to Malawians. That the leadership fell far short of condemning it and demanding its

16 See http://munthalikondwani.blogspot.com/2012/04/full-ccap-nkhoma-synod-pastoral-letter. html, accessed 5/3/12.

17 See http://munthalikondwani.blogspot.com/2012/04/full-ccap-nkhoma-synod-pastoral-letter. $\underline{\mathrm{html}}$, accessed 5/3/12. 
repeal is strange 'only serving the interests of a few.' One gets the impression from the Letter that in the view of the leadership 'prayer' was a panacea to the social evils and human rights abuse in Malawi.

Commenting on this law on 25th June 2012, President Bakili Muluzi, stated, 'those laws virtually robbed Malawians of their social freedom privately and publicly' (Interviews, former President, Bakili Muluzi, Stellenbosch, 17/06/12; Reverends Davidson Chifungo and Bosman Chitheka, Stellenbosch, 25/03/12).

However, the differences in the style and approach regarding the Roman Catholic Pastoral Letter of 31 October 2010 and the Nkhoma Synod Pastoral Letter lie in the fact that the Catholic Church had a longer tradition of drafting and promulgating Pastoral Letters on which it relied while for the Nkhoma Synod it was the first time that it promulgated one.

Nonetheless, the Pastoral Letter provoked a response from the government. The Civic Education Minister, Mrs Patricia Kaliati, claimed that the Church leaders' motive to write the letter was the unfulfilled pledge of K10 M (\$59 880) by the President (Nyasa Times 03/04/12).$^{18}$ It would seem that Mrs Kaliati's claim was not entirely misplaced. This has been disputed by some Church leaders. For instance, Reverend Macdonald Kadawati argued that 'the minister tried to detract from the real national issues that the nation was facing' (Questionnaire/ Interview, 17/06/12).

The 2 April 2012 Pastoral Letter followed the one which was drafted in 2011 and was signed by 32 clergy The Letter was never promulgated as the senior leaders of the Synod refused to endorse it (Interview, Reverend Dr. Zeze, Stellenbosch, 05/03/12). Since the leaders did not endorse the Letter, their action created perceptions that they sympathised with the government (Interview, Reverend John Gondwe, Stellenbosch, 05/03/12). Though the Letter addressed issues similar to the 2010 Catholic Bishops' Letter nonetheless it raised critical issues that demanded urgent solutions. After faltering for a while, and despite joining the others late in the struggle for human rights, it was a courageous stance on the part of the Nkhoma Synod clergy; their voice added to that of many in society who were crying for justice

\section{MALAWIAN CULTURE/S AND HUMAN RIGHTS}

\subsection{Gay rights opposed to Malawian culture?}

No issue in Malawi has demonstrated the difficulty of understanding on one hand the interface between human rights and Malawian cultural view relating to

18 Nyasatimes.com/Malawi, accessed 25 May 2012. 
sexual orientation and Christian morality on the other as gay rights. The arrest of the 'homosexual' couples, Chimbalanga and Mongeza and their conviction to 14 years in prison in 2010 in Malawi caused an international furore much like the homosexual death sentence bill passed in Uganda two years ago. The UN Secretary General, Ban Ki-Moon's swift flight to Malawi to plead for their clemency signified this. ${ }^{19}$ The Churches' response that homosexuality was against Malawian culture and unchristian raised further criticism from amongst others, the NGOs. ${ }^{20}$

The Malawi Council of Churches, representing the Protestant Churches in Malawi, advised the government to retain current laws against homosexuality in the criminal code and to disregard the pressure from donor countries, advising the countries to 'respect Malawi's cultural and religious values and refrain from using aid as a means of forcing the country to legalise sinful acts like homosexuality in the name of human rights.' On the other hand, the Catholic Archbishop of Blantyre, Tarcisius Gervazio Ziyaye, never issued a statement either in favour of the sentence or in condemnation of the treatment, ${ }^{21}$ but the NGOs condemned the government and the Churches for their harsh reaction towards a homosexual couple. As it were, common opposition to homosexuality seemed to unite the Churches and the government.

The episode raised the issue of how a country that subscribed to the UN charter of human rights could deprive a 'gay couple' of their rights to sexual orientation. The Churches disapproval of homosexual rights may suggest inconsistency on their part as the Churches supported all other rights as enshrined in the constitution. Or it may also imply that the Churches did not fully understand the secular notion of human rights. Yet at stake here is also the issue whether gay rights conflicted with Malawian/cultural norms of sexual behaviour.

According to Thoko Kaime, 'Culture profoundly affects the articulation and implementation of any social standards because of its function and constant influence on human motivation and behaviour (Kaime 2009: 172).' He further argued that, 'The ability of members of a cultural tradition to take alternative courses of action is conditioned by the broad parameters of their culture' (173). The Church leaders' argument invoking culture and religion shows the extent to which these factors have influenced their and Malawians' view of human rights. Even though there is no such thing as 'a homogeneous culture', nevertheless basic common principles of behaviour underlie almost all tribal cultural norms in Malawi and by extension Africa.

19 http://af.reuters.com/article/topNews/idAFJOE64506I20100529, accessed May 18, 2012.

20 http://www.voanews.com/content/butty-malawi-gays-church-18march10-88325027/15377. $\underline{\mathrm{html}}$, accessed June 18, 2012.

21 http://en.wikipedia.org/wiki/LGBT rights in Malawi, accessed May 20, 2012. 
Though Malawian languages do not have the concept of 'human rights' in their vocabulary, nonetheless, traditionally Malawian cultural norms have always conceived the dignity of the persons, not in terms of asserting the 'individual' rights, rather as an intrinsic part of the 'rights of the community.' The Malawian notion of human rights is entailed in the saying 'birth rights' conceived as ufulu wachibadwidwe, denoting some 'entitlement' to rights.

But as de Gaay Fortman argued, 'Whereas international human rights do not in any way refer to spiritual roots of the conviction that human dignity must be protected against any abuse of power, in an African setting it is abundantly clear that human rights is a mission that cannot be separated from people's religious convictions' (2004: 9). In other words, culture and religious convictions influence the interpretation and understanding of human rights. Thus Western cultural norms have to be received and interpreted within the framework of a local culture otherwise they lose their authenticity. Local cultural tools therefore constitute the only criteria on which a cultural norm has to be judged and interpreted and therefore considered valid.

Finally, there is no doubt whatsoever that the promotion of human rights has been a positive development in Malawi. However tendencies of anti-social behaviour have also surfaced which appear to undermine some positive aspects of traditional values of communal life. Today in contrast to the 'disciplined' social life which was imposed and regulated under the Banda regime it is not uncommon to hear or see some young people displaying arrogant behaviour to their parents or some senior members in the community in the name of ufulu wachibadwidwe. For instance, in 2007, the author experienced a situation in a bus where a young man to the dismay of the other passengers, refused to surrender his seat to an elderly sickly man because as he claimed 'he had more right to sit there than the old man.' In this respect, human rights viewed as entitlements border on disrespect or arrogance. There are others who refuse to get involved in community work in the villages as they proclaim their 'birth-right freedom.' In this case, insolence or irresponsibility is confused with exercise of one's human rights.

\section{CONCLUSION}

In the preceding discussion, I have shown that the Churches responded to the issue of human rights on two levels. The first area involved the work of human rights projects in the Churches, which through its programmes tried to make people aware of their rights. In this respect, the role of the international donor community in funding the Churches' human rights projects and the NGOs was critical to the promotion of human rights culture in Malawi. The second category entailed the Church leaders issuing public statements in the press or in the form of Pastoral 
Letters addressed more immediately to their faithful and more widely to the nation. This form of the Churches' social witness was fairly strong in denouncing the abuse of human rights and drawing the government's attention to governance issues. That the government adopted an adversarial attitude to the Church leaders and others suggests the extent to which the Church leaders had become effective in speaking for the voiceless majority. Nonetheless, in some respects their social witness was not consistent enough as they failed to uphold the rights of a 'homosexual couple.' To some extent their witness was undermined by two major factors, namely: divisions in its ranks, which were attributed to intimidation, harassment, and in some cases violence perpetrated by state agents and its officials against its critics. Divisions in the Churches were said to be enhanced by the office of the Presidential Advisor on Religious Affairs who allegedly offered financial rewards to some clergy. It has also been highlighted that the Wa Mutharika government's adversarial attitude to the Church leaders and other critics reflected Malawian cultural intolerance to opposition and rival leaders that challenged government.

The issue of gay rights in the context of Malawian culture raises a question whether human rights as a Western construct conflict with the norms of a particular culture? The other question that is equally valid is, are human rights meant to be universally valid? Or do they have to be superimposed on a local culture? To what extent can human rights supersede the cultural norms of conduct? These are issues that would need further study. Though Malawian languages do not have the concept of 'human rights' in their vocabulary, nonetheless, traditionally Malawian cultural norms have always maintained the dignity of the persons within the framework, not of the 'individual' but rather as an intrinsic part of the communities. Western cultural norms have to be received and interpreted within the framework of a local culture otherwise they risk being irrelevant in the particular context. Local cultural tools therefore constitute a critical framework in which universal human rights can be interpreted and received.

\section{BIBLIOGRAPHY}

Englund, Harri, 'The dead hand of human rights: contrasting Christianities in post-transition Malawi', The Journal of Modern African Studies. http://journals. cambridge.org/abstract_S0022278X00003487

Gaay Fortman, B. de in Kwame Bediako et al (eds.). 2004, A New Dawning, African Christians Living the Gospel. Zoetermeer (NL): Boekentrum, http://igitur-archive. library.uu.nl/law/2009-0715-201436/UUindex.html accessed 18 June 2012. 
Gama, B. (2010). The Role of the Church in Politics in Malawi. Kempton Park: AcadSA.

Kaime, (2009). African Charter on the Rights and Welfare of the Children: A Sociolegal Perspective. Pretoria: Press PULP.

Mufuka, K. N. (1977). Missions and Politics in Malawi. Kingstone and Ontario: Limestone Press.

Malawi Today 20/08/10. ${ }^{22}$

The Nation, $2 / 11 / 10 .{ }^{23}$

The Maravi Post, 22/5/11.

Nyasa Times, $25 / 08 / 11 .^{24}$

Nyasa Times 03/04/12. ${ }^{25}$

Reverend Levi Nyondo, the General Secretary of the Presbyterian Synod of Livingstonia Synod was arrested (Malawi Today 20/08/10). ${ }^{26}$

Questionnaire/Telephone Interviews, Reverend Macdonald Kadawati, 15/05/12; $21 / 05 / 12$

Interview, Reverends Davidson Chifungo and Bosman Chitheka, Stellenbosch, 25/03/12).

Interview, Reverend John Gondwe, Stellenbosch, 05/03/ 12

Questionnaire/Telephone Interviews, Reverend Father Macdonald Kadawati, $15 / 05 / 12 ; 21 / 05 / 12$

Interview, Reverend Dr. Willie Zeze, Stellenbosch, 05/03/12.

22 http://www.malawitoday.com/news/123279, accessed June 18, 2012.

23 http://www.trademarksa.org/news/malawi-full-pastoral-letter-catholic-bishops, accessed June 20, 2012.

24 http://www.nyasatimes.com/Malawi/2011/08/25/Mutharika-attacks-bishop-zuza, accessed May 10, 2012.

25 Nyasatimes.com/Malawi, accessed 25 May 2012.

26 http://www.malawitoday.com/news/123279, accessed June 18, 2012. 
Interview, Reverends Davidson Chifungo and Bosman Chitheka, Stellenbosch, 25/03/12.

Questionnaire, Reverend Mezuwa Banda, 06/05/12

Questionnaire/Telephone Interviews, Macdonald Kadawati, 15/05/12; 21/05/12

Questionnaire, James Tengatenga, 07/06/12

Interview, former President, Bakili Muluzi, Stellenbosch, 17/06/12

Questionnaire/Telephone interview, Macdonald Sembereka, 08/06/12

\section{KEY WORDS}

Malawi

Human dignity

Human Rights

Churches

Catholic

Protestant

\section{TREFWOORDE}

Malawi

Menswaardigheid

Menseregte

Kerke

Katoliek

Protestant

\section{CONTACT DETAILS}

Dr Henry Mbaya

Stellenbosch University

Faculty of Theology

Private Bag X1 7602

MATIELAND

E-mail:hmbaya@sun.ac.za 